\title{
A COMPANY'S PROACTIVE MARKETING ORIENTATION IN THE HIGH-TECH SECTOR
}

\author{
Tomasz GRZEGORCZYK \\ Department of International Management, Poznan University of Economics and Business; \\ tomasz.grzegorczyk@ue.poznan.pl, ORCID: 0000-0002-4286-5753
}

\begin{abstract}
This paper links the characteristics of new product development in the high-tech sector with the marketing orientation of the firm, especially in its proactive form. The purpose of the paper is to define the characteristics of competition and innovation creation in the hightech B2C sector and assess whether the marketing orientation of the enterprise may be an answer to those characteristics. Creating innovation in the high-tech sector is difficult due to technological and market (consumer) uncertainty, as well as competitive volatility. This significantly increases the risk of market failure of new products, especially in the case of radical innovations. The way firms may counteract this risk is to adopt a market orientation. Particularly important is its proactive dimension, which involves researching and anticipating future and latent consumer needs. Firms developing new products in the high-tech sector should pursue the proactive marketing orientation and consequently focus on the latent and future consumer needs. Methods stemming from future studies and foresight might be useful in achieving this goal. The methodology used in the paper was the selective literature review in the area of new product development in the high technology sector and marketing orientation of the firm.
\end{abstract}

Keywords: new product development, high-tech sector, marketing orientation, consumer orientation.

\section{Introduction}

Most innovations are created in the high-tech sector. The process of their creation is characterised by specific conditions, as is the character of competing in this sector. High technologies mean the newest, most advanced technologies, which e.g. include robotics, nanotechnology or aviation technologies. High-tech companies "are involved in the design, development and marketing of new products and/or innovative production processes through the systematic application of scientific and technical knowledge" (Hecker, 2005, pp. 57-72). Research and development (R\&D) departments play a key role in these companies, allowing them to create radical product innovations in opposition to imitative innovations, which are more common in other industries (OECD, 2005, p. 37). 
Mick and Fournier point out that high technologies create a paradox for consumers, because they generate both positive and negative emotions that can lead to conflict and fear (1998). Therefore, one cannot be sure of the adoption of technologically innovative products by consumers. This may indicate the need for the company to adopt a marketing orientation.

The purpose of this selective literature review is to define the characteristics of competition and innovation creation in the high-tech $\mathrm{B} 2 \mathrm{C}$ sector and to evaluate whether the marketing orientation of an enterprise may be an answer to these characteristics, and if so, then how?

\section{Methods}

This paper is a selective literature review in the area of new product development in the high technology sector and the marketing orientation of a firm. A selective approach was chosen due to the aim of this study. The following databases were searched: Emerald, ProQuest, Wiley Online Library, Taylor \& Francis and ScienceDirect, as well as Google and Google Scholar. The following phrases were used: "high-tech sector characteristics", "high-tech competition", "marketing orientation", "consumer uncertainty". In order to obtain more relevant publications, the search concentrated on specific criteria: language - English or Polish, refined by categories - management or economics or business, timespan - 1980-2020. Publications which focused on the characteristics of competing in the high-tech B2C (business-to-consumer) sector and proactive and responsive marketing orientation in this sector were selected.

\section{The characteristics of competing in the high-tech sector}

The consumer goods market in high-tech industries is one of the most dynamically developing in the world (Wiechoczek, 2016, p. 231). High-tech industries are characterised by special features that make competing particularly demanding, although potentially very profitable. The specificity of the high-tech sector consists primarily of volatility and multidimensional uncertainty among enterprises and consumers.

\subsection{High-tech sector volatility}

The competitive volatility of the high technology sector means that companies cannot be sure with whom (the variability of competition), with which products (the variability of the subject of competition) and with what methods (variability of the business strategy) they will compete against even in the near future (Mohr, Sengupta, and Slater 2010, p. 11). 
Among others, this is a result of the convergence - the linking of various technology industries. An example is the smartphone, which is the successor to a traditional mobile phone, which unexpectedly became dangerous competition for portable game consoles. Moreover, rivals from other industries are often more unpredictable in introducing new business models. An example is the introduction of Skype, which allows one to make free Internet calls around the world, which surprised rivals basing their income on long-distance calls.

\subsection{Firms' uncertainty in the high-tech sector}

There is uncertainty on the side of entrepreneurs as to the time needed to introduce technologically advanced products to the market (Mohr, Sengupta and Slater, 2010, pp. 14-15). The time it takes to achieve this is usually longer than for other products. Postponing the market premiere of a product has a negative impact on the satisfaction of the consumers, who can opt for a product offered by competitors. Furthermore, due to technological developments, neither the producer nor the consumer can be certain how long a given technology will remain in use and when it will become obsolete. Moreover, the market for advanced technologies is often regulated by the government and international organisations, which further increases the uncertainty of doing business (Viardot, 2004, pp. 21-23). In order to remain competitive in the high-tech sector, a constant ability to introduce innovations is necessary as a consequence of a shorter product life cycle. For example, Moore's (Intel's founder) law says that processor performance doubles every 18 months without raising the prices (Moore, 1965). To maintain this pace, it is necessary to conduct continuous, intensive research. The associated high expenditure on $R \& D$ is another feature of this sector, in which the automotive industry excels (Viardot, 2004, pp. 17-19). The development of the high-tech sector is also affected by the phenomenon of knowledge spillover. This means that technological advances in one area influence other branches. Therefore, companies should carefully monitor the state of knowledge not only in their industry, but also in others. Another phenomenon is the merger of technologies, i.e. combining previously different areas of technical knowledge, which increases the uncertainty of this sector. An example is the success of NEC, whose president predicted a merger of the IT sector with telecommunications (Klincewicz, 2016, p. 116). Technological uncertainty is also increasing, as many high-technology products incorporate not one technology, but several technologies (Dhebar, 2016).

The high-tech sector is particularly susceptible to the network effect, meaning that the more popular a given product or service is, the greater its value for consumers (Hirynyawipada, and Paswan, 2006, p. 187). A direct network effect occurs when the value of a product or service increases with the number of users, as exemplified by the telephone in the first half of the 20th century (Fisher, and Oberholzer-Gee, 2013, p. 162). If the market was not sufficiently saturated with this once technologically advanced device, it would prove to be not very useful for its initial buyers. In turn, the indirect network effect is based on complementary goods that increase the value of the basic product and vice versa. A computer with software is a good 
example. The network effect is associated with the need to follow market standards, e.g. in the field of interfaces. The increase in product compatibility with other consumer devices increases its perceived value. Table 1 . shows industries ranked by the level of uncertainty. Apart from agriculture, all of them belong to the high-tech sector.

Table 1.

Industries ranked by the level of uncertainty

\begin{tabular}{|c|c|c|c|c|}
\hline & INDUSTRY & $\begin{array}{l}\text { R\&D } \\
\text { OF SALES }\end{array}$ & $\begin{array}{l}\text { REVENUE } \\
\text { VOLATILITY }\end{array}$ & $\begin{array}{l}\text { FIRM } \\
\text { TURNOVER }\end{array}$ \\
\hline 1 & Medical equipment & $8.2 \%$ & $90.7 \%$ & $13.1 \%$ \\
\hline 2 & Computers & 5.8 & 98.8 & 12.0 \\
\hline 3 & Computer software & 9.8 & 69.9 & 14.4 \\
\hline 4 & Pharmaceutical products & 17.4 & 63.3 & 12.7 \\
\hline 5 & Measuring \& control equip. & 9.3 & 97.0 & 8.8 \\
\hline 6 & Machinery & 3.2 & 100.5 & 9.3 \\
\hline 7 & Agriculture & 10.8 & 123.3 & 4.9 \\
\hline 8 & Electronic equipment & 5.2 & 61.5 & 10.5 \\
\hline 9 & Chemicals & 3.0 & 71.2 & 9.2 \\
\hline 10 & Electrical equipment & 9.8 & 35.0 & 9.2 \\
\hline
\end{tabular}

Source: Dyer et al., 2014.

\subsection{Consumer uncertainty in the high-tech sector}

The market uncertainty of the high technology sector is manifested as uncertainty about a product's value for the consumer, as well as a consumer's future needs. The rate at which the technology spreads is unknown, as well as is the associated difficulty in assessing the size of the market (Moriarty, and Kosnik, 1989, p. 8). Kline and Rosenberg point out that the more innovative a new product is and the more significant changes it introduces, the greater the uncertainty associated with it (1986, p. 276). The sources of uncertainty can also be divided according to economic (e.g. income), socio-demographic (e.g. age, gender and education), cultural (e.g. religion) and psychological (e.g. personality) consumer factors (Tkaczyk, and Awdziej, 2009).

Technological uncertainty in the high-tech market encapsulates, among others, uncertainty as to whether an innovative product will work properly and, as a result, if it will meet the consumer's expectations (Mohr, Sengupta, and Slater, 2010, pp. 14-15). Moreover, in the case of technologically advanced products, there is a widespread belief that there is a greater risk of failure, which may raise concerns regarding the possibility and cost of repairs. Consumers may also wonder if such a product will act as promised by the manufacturer, for example in terms of its usability, performance and reliability (Sarin, Sego, and Chanvarasuth, 2003, pp. 71-72). It is the functional dimension of the uncertainty that has a particularly negative impact on the intention to adopt products from the high-tech sector (Ziamou, and Ratneshwar, 2002, pp. 341342). Consumers may also be concerned about their ability to use a technologically advanced product, as well as about the uncertainty related to the lack of understanding of the mechanism of its operation. This is becoming more and more common nowadays, as the number of new 
technologies and their complexity is growing rapidly (Philips, and Hallman, 2013, pp. 741742). Technology literacy and especially IT literacy play a role in the degree of technological uncertainty. However, even for tech savvy consumers, the principle of a high-tech product's operation may not be presumed due to the protection of the intellectual property of the company (Hall, Bachor, and Matos, 2014, p. 413). In addition, features such as durability and reliability are revealed only in the process of use, and they are consequently difficult to evaluate before buying. The consumer may, therefore, be worried about whether such a technologically complex product will break down and whether, in the event of a failure, it can be easily repaired, and if so, whether such repairs will be quick and inexpensive. Another key issue is the fear of the physical consequences of a possible malfunction.

The magnitude of consumer uncertainty depends on the high-tech product. The more consumers have experience in using a particular product, the less risk is perceived (Frąckiewicz, 2009 , p. 222). Naturally, for new types of high-tech products, there is very little chance that consumers have any experience in their use. Moreover, consumers may be uncertain as to which consumer needs the given technology fulfils (Mohr, Sengupta, and Slater, 2010, pp. 12-13). Another issue is the short lifespan of technologically advanced products, which, combined with the high purchase price and rapid depreciation of value, increases the purchase risk perceived by the consumer. In addition, consumer needs are changing, which, combined with the desire to have the latest products, increases the risk of purchase. Consumers also face the risk that their product will be replaced by another technological market standard (Sarin, Sego, and Chanvarasuth, 2003, p. 72). For example, in 2007, two different types of high definition DVD players were introduced to the market: Sony Blu-Ray and Toshiba HD-DVD. The movie purchased by the consumer could only be compatible with one of these two types of players. Consumers' doubts as to which of these formats would become dominant effectively discouraged them from making purchase decisions, which resulted in a significant slowdown of the diffusion rate of these technologies (Mohr, Sengupta, and Slater, 2010, p. 12). Ultimately, the Blu-Ray format displaced HD-DVD, and customers who chose the latter player had to reconcile with the fact that from 2008, they were not able to watch new films on their device. Therefore, industrial standards play a role in either reducing consumer risk (when they are introduced) or increasing consumer risk (when they are lacking). All in all, due to such the large and multidimensional role of uncertainty in the high-tech sector, all actions aimed at reducing this are of particular importance.

Most companies offering technologically advanced products have a marketing communication strategy aimed at increasing the acceptance of their products by decreasing the associated risks (Philips, and Hallman, 2013, p. 739). Enterprises use various strategies to reduce perceived technological risk. An example is offering products as part of a bundle, which includes products considered safe (because of a known brand or popularity) and products considered risky due to unknown, advanced technology (Sarin, Sego, and Chanvarasuth, 2003). Manufacturers can also take a number of formal and legal measures to reduce the risk perceived 
by the consumer. These include, for example, the manufacturer's legal liability for damages caused by the product (product liability), granting the right to return the product or providing a guarantee (Taranko, and de Pourbaix, 2009, p. 184). Furthermore, in the case of applied artificial intelligence, such as medical assistive devices (IBM's Watson, Fraunher IPA's Care-O-bot 3, AiCure) and autonomous vehicles (BMW, Daimler, Deutsche Bahn), trust in the manufacturer (of both hardware and software) is especially important in reducing the consumer's uncertainty (Hengstler et al., 2016).

\section{Proactive and responsive marketing orientation in the high-tech sector}

Initially, competition in the high-tech sector was mainly based on the fast and simultaneous introduction of radical and incremental innovations (Mohr, Sengupta, and Slater, 2010). At present, however, this approach is no longer sufficient due to hypercompetition (D'Aveni, 1997). Companies are forced to seek sources of competitive advantage elsewhere, in particular in marketing activity (Wiechoczek, 2016, p. 231). The marketing orientation of high-tech enterprises results in better new product performance, as well as the overall higher effectiveness of the company (Im and Workman, 2004). Marketing orientation means collecting, sharing and using market information (about consumers, consumer trends or competition) in order to make better strategic decisions, including the process of developing a new product (Mohr, Sengupta, and Slater, 2010, p. 4). Marketing orientation allows for the reduction of uncertainty for a company. This approach underlines that it is important to develop products tailored to the specific expectations of customers. This is possible thanks to the enterprise's understanding of the clients' needs, with whom it maintains relations in order to determine the core values that will be expected in the future (Wiśniewski, 2016, p. 325).

The process of developing a new product is usually divided into the following stages: idea search, evaluation and selection of ideas, concept development and testing, marketing strategy preparation, business analysis, product development, market tests and commercialisation. According to Armstrong and Kotler, customers play a key role in searching for an idea, and they are the most important source for this (2012, p. 363). The cited authors note, however, that, especially in the case of technologically advanced products, companies cannot be limited to the needs of consumers, and sources of ideas for innovation should be diverse. Wiechoczek (2015) also draws attention to the limited role of consumers as a source of ideas for innovations in the high technology sector.

However, at other stages, such as concept testing or market testing, consumer participation is essential. The results of empirical research indicate that consumer-focused marketing orientation is conducive to the creation of radical, novel innovations (Lukas, and Ferrell, 2000). Thus, less imitative innovations are created ("me-too innovation"). However, in the case of 
enterprises focused more on researching the activities of competition, this relationship is inverse. This underlines the importance of research on the determinants of the acceptance of innovations by consumers.

Consumers are becoming a more important innovation resource (Tidd, and Schweitzer, 2018). Companies must decide whether to concentrate on existing customers and markets or on new customers and markets (Lamore, Berkowitz, and Farrington, 2013). Marketing orientation can be divided into responsive and proactive (Narver, Slater, and MacLachlan, 2004). In the case of the former, the company primarily focuses on current consumers and their existing, expressed needs. Responsive orientation is also characterised as being market demand driven, meaning that the marketing department identifies new product opportunities and communicates with R\&D to develop innovative solutions to expressed customer needs (Lamore, Berkowitz, and Farrington, 2013). However, this strategy has disadvantages, including a limitation of innovation. That is why Mohr, Sengupta and Slater are in favour of a proactive marketing orientation, which is based on attempts to predict and meet the latent and future needs of consumers (2010, p. 107). This is regarded as invention driven, meaning that the R\&D departments search for innovative solutions. When latent needs are not met by consumers, there is no sign of dissatisfaction or any other response. However, when a company manages to discover such a need and satisfy this, it often gains a loyal customer.

Despite the above, in the case of radical innovations, the cooperation between the R\&D department and the marketing department is particularly important - even at the initial stages of product development. This is due to the fact that the applications of a new technology may be too numerous or unexpected by the consumer (Mohr, Sengupta, and Slater, 2010, p. 122). Jointly defining the industry and the market in which the product will compete and setting expectations and priorities increase the chances of success in sales. The findings of empirical research confirm that new products of enterprises in which the marketing and R\&D departments work closely together more often achieve success (Mohr, Sengupta, and Slater, 2010, p. 121). Lamore, Berkowitz and Farrington (2013) showed that a high degree of synergy is developed between the R\&D and marketing department when the focus is on future market needs. Proactive market orientation exhibits a positive relationship with market performance, while responsive market orientation does not. Moreover, responsive customer orientation diminishes the ability to reduce product-related uncertainties at the fuzzy front end of innovation (meaning the early stages of innovation creation) (Schweitzer et al., 2018).

Some studies reach for even more detailed methods of analysis. For example, Im and Workman divided the aspect of product innovation in the high-tech sector into its novelty and relevance $(2004$, p. 115). Novelty is measured as the degree to which new products are unique and different from the competition, and relevance - as the degree to which they are seen as impactful and useful to consumers. The results show that if a company cooperates closely with consumers during product development, relevant products are more often created. However, when a company focuses on observing competition as part of its marketing orientation, it more 
often creates novel products. It also turns out that the commercial significance of the product is related more to the relevance dimension, which confirms the importance of consumer research of products at the research and development stage (Im, and Workman, 2004, p. 127).

Narver et al. (2004) hypothesised that both forms of market orientation would be positively linked with the success of a new product, with proactive market orientation exhibiting a greater impact. Their results show that proactive market orientation indeed exhibited a positive relationship, while responsive market orientation exhibited a negative relationship with the success of a new product. Moreover, the creation of gradual innovations is helped by responsive marketing orientation, while the formation of radical innovations - proactive marketing orientation (Atuahene-Gima, Slater, and Olson, 2005). In addition, a proactive strategy can lead to a market structure redefined by value innovation and by creating a "blue ocean" where there is no competition at all (Chan Kim, and Mauborgne, 2005). Such attempts are generally very risky, which is why a proactive marketing orientation allows for a reduction of the increased risk. The actions that lead to this are primarily market research on future, non-existent products, observation of consumer habits or cooperation with active users (Sundbo, 1998, p. 152; Mohr, Sengupta, and Slater, 2010, p. 107). This allows for the creation of products with the features and functionalities desired by consumers.

Different views are also present in literature. Von Hippel states that the average user of today's products has no experience with the products of the future (1984). Goldenberg and Mazursky believe that consumer research is an effective method to learn about product strengths and weaknesses, match new products to customer needs or forecast product success and sales, but it is no longer a source of ideas for future radical product innovations (2005, pp. 14-15). This stays in accordance with the findings that the role of the marketing department (responsible for understanding the needs of customers) is increasing along with the time left to the market debut of a new product (Mohr, Sengupta, and Slater, 2010, p. 122). In addition, many ground-breaking innovations are initiated under the supply-push innovation model (Markides, 2006, pp. 22-23).

\section{Future research}

This paper has linked the characteristics of innovation creation in the high-tech industry with the marketing orientation of a firm, pointing out the usefulness of proactive marketing orientation. Nevertheless, there still exists a need to reconfirm such a causal connection, as existing research is scarce.

Moreover, there are still many other unanswered questions. For example, one could research if there are particular high-tech industries which benefit more from a proactive orientation. Another question arises - are there particular high-tech industries which possibly benefit, 
differently than the majority of the high-tech sector, from a passive marketing orientation? If yes, why is this?

Furthermore, if proactive marketing orientation focuses on future and latent consumer needs, is an invention push coming solely from the R\&D department really sufficient? There are ways of studying both latent and future consumer needs. For example, latent attitudes can be measured by the Implicit Association Test (Maison, 2004). When it comes to future attitudes, there is a wide array of methods stemming from future studies and strategic foresight, which may allow one to predict the possible future and latent needs of consumers. These are e.g. the scenario method, Delphi method (e.g. Merfeld et al., 2019) or trend analysis. Other methods, such as studying consumers' technology acceptance of as yet non-existing products, strategic workshops, co-designing (Mencarini et al., 2019) and design thinking methods (e.g. Micheli et al., 2019) may also be helpful. Another source of information is Big Data, which, paired with data science, allows one to gain deep insight into consumer attitudes and behaviour (Erevelles et al., 2016). Therefore, exploring the popularity of these methods for new product development in the high-tech sector, as well as the relation of their introduction with the success of a new product, is suggested.

\section{Summary}

The technological advancement of a product is not in itself desirable by the market (Kline, and Rosenberg, 1986, p. 278). The value of a product for a consumer is created by the difference between advantages and cost (Viardot, 2004, pp. 5-6). In addition, the significant role of cooperation in developing innovations (especially radical ones) between the marketing department and the R\&D department should be emphasised. Unexpectedly, the importance of this cooperation rises with the increase in the degree of advancement of innovation and uncertainty of the environment (Mohr, Sengupta, Slater, 2010, p. 122).

Creating innovation in the high-tech sector is also difficult due to technological and market uncertainty, as well as competitive volatility. This significantly increases the risk of market failure, especially in the case of radical innovations. The way to counteract this risk may be to adopt a market orientation, as it allows one to reduce the sector's uncertainty. Particularly important is its proactive dimension, which involves researching and anticipating future and latent consumer needs, as well as in the context of new innovative products that are under development. This assumes cooperation with consumers, including research on consumer attitudes towards an innovative product already at the stage of its development, i.e. before it reaches the market. While proactive market orientation exhibits a positive relationship with market performance, responsive market orientation does not. Moreover, responsive customer 
orientation diminishes the ability to reduce product-related uncertainties at the early stages of innovation creation.

Novel directions of future research are indicated, and among them are methods aimed at lowering uncertainty: the scenario method, Delphi method, trend analysis, studying consumers' technology acceptance of as yet non-existing products, strategic workshops, co-designing, design thinking methods, as well Big Data analysis.

\section{References}

1. Tidd, J., Schweitzer, F. (2018). Innovation heroes: Understanding customers as a valuable innovation resource. In: J. Tidd, J.R. Bessant (eds.), Managing Innovation. Integrating Technological, Market and Organizational Change, 1-295. https://doi.org/10.1142/q0158.

2. Dhebar, A. (2016). Bringing new high-technology products to market: Six perils awaiting marketers. Business Horizons, 59(6), 713-722.

3. Mencarini, E., Leonardi, C., Cappelletti, A., Giovanelli, D., De Angeli, A., \& Zancanaro, M. (2019). Co-designing wearable devices for sports: The case study of sport climbing. International Journal of Human Computer Studies, 124(July 2018), 26-43. https://doi.org/ 10.1016/j.ijhcs.2018.10.005.

4. Schweitzer, F., Palmié, M., \& Gassmann, O. (2018). Beyond listening: the distinct effects of proactive versus responsive customer orientation on the reduction of uncertainties at the fuzzy front end of innovation. $R \& D$ Management, 48(5), 534-551. https://doi.org/10.1111/ radm. 12252 .

5. Armstrong, G., Kotler, P. (2012). Marketing. Wprowadzenie. Warszawa: Pearson Education Inc.

6. Atuahene-Gima, K., Slater, S.F., and Olson, E.M. (2005). The Contingent Value of Responsive and Proactive Market Orientations for New Product Program Performance, Journal of Product Innovation Management, 22, 464-482.

7. Chan Kim, W., and Mauborgne, R. (2005). Strategia błękitnego oceanu: jak stworzyć wolna przestrzeń rynkowa $i$ sprawić, by konkurencja stała się nieistotna. Warszawa: Wydawnictwo MT Biznes.

8. D'Aveni, R.A., and Gunther, R.E. (1994). Hypercompetition: Managing the dynamics of strategic maneuvering. New York: The Free Press.

9. Dyer, J., Furr, N., Lefrandt, C. (2014). The industries plagued by most the most uncertainty. Harvard Business Review, hbr.org.

10. Erevelles, S., Fukawa, N., \& Swayne, L. (2016). Big Data consumer analytics and the transformation of marketing. Journal of Business Research, 69(2), 897-904. https://doi.org/ 10.1016/j.jbusres.2015.07.001. 
11. Fisher, W.W., and Oberholzer-Gee, F. (2013). Strategic Management of Intellectual Property: An Integrated Approach, California Management Review, 55(4), 157-184.

12. Frąckiewicz, E. (2009). Ryzyko cyfrowe nabywcy - pojęcie i znaczenie. In: L. Garbarski, J. Tkaczyk (eds.), Kontrowersje wokół marketingu w Polsce. Niepewność i zaufanie a zachowania nabywców (pp. 220-229). Warszawa: Wydawnictwo Akademickie i Profesjonalne.

13. Goldenberg, J., and Mazursky, D. (2002). Creativity in product innovation. Cambridge: Cambridge University Press.

14. Hall, J., Bachor, V., and Matos, S. (2014). The impact of stakeholder heterogeneity on risk perceptions in technological innovation. Technovation, 34(8), 410-419. http://doi.org/ 10.1016/j.technovation.2013.12.002.

15. Hecker, D.E. (2005). High-technology employment: NCAIS based update. Monthly Labor Review, June.

16. Hengstler, M., Enkel, E., \& Duelli, S. (2016). Applied artificial intelligence and trust The case of autonomous vehicles and medical assistance devices. Technological Forecasting and Social Change, 105, 105-120. https://doi.org/10.1016/j.techfore. 2015.12.014.

17. Hirunyawipada, T., and Paswan, K. (2006). Consumer innovativeness and perceived risk: Implications for high technology product adoption. Journal of Consumer Marketing, 23(4), 182-198. http://doi.org/10.1108/07363760610674310.

18. https://doi.org/10.1016/j.bushor.2016.08.006.

19. Im, S., and Workman, J.P. (2004). Market Orientation, Creativity, and New Product Performance in High-Technology Firms A. Journal of Marketing, 68, 114-132. http://doi.org/10.1509/jmkg.68.2.114.2778.

20. Klincewicz, K. (2016). Zarządzanie technologiami - perspektywa organizacjiużytkownika. In: K. Klincewicz (ed.), Zarządzanie, organizacje i organizowanie-przeglad perspektyw teoretycznych (pp. 110-123), Warszawa: Wydawnictwo Naukowe Wydziału Zarządzania Uniwersytetu Warszawskiego.

21. Kline, S., and Rosenberg, N. (1986). An overview of innovation. In: R. Landau, N. Rosenberg (eds.), The Positive Sum Strategy. Harnessing Technology for Economic Growth. Washington: National. Academy Press.

22. Lamore, P.R., Berkowitz, D., and Farrington, P.A. (2013). Proactive/responsive market orientation and marketing - Research and development integration. Journal of Product Innovation Management, 30(4), 695-711. https://doi.org/10.1111/jpim.12024.

23. Lukas, B.A., and Ferrell, O.C. (2000). The effect of product orientation on product innovation, Journal of the Academy of Marketing Science, 28(2).

24. Maison, D. (2004). Utajone postawy konsumenckie. Sopot: GWP. 
25. Markides, C. (2006). Disruptive Innovation: In Need of Better Theory. Business-Model Innovation. Harvard Business Review, 23, 19-25. http://doi.org/10.1111/j.1540-5885. 2005.00177.x.

26. Merfeld, K., Wilhelms, M.P., Henkel, S., and Kreutzer, K. (2019). Carsharing with shared autonomous vehicles: Uncovering drivers, barriers and future developments - A four-stage Delphi study. Technological Forecasting and Social Change, 144(March), 66-81. https://doi.org/10.1016/j.techfore.2019.03.012.

27. Micheli, P., Wilner, S.J.S., Bhatti, S.H., Mura, M., and Beverland, M.B. (2019). Doing Design Thinking: Conceptual Review, Synthesis, and Research Agenda. Journal of Product Innovation Management, 36(2), 124-148. https://doi.org/10.1111/jpim.12466.

28. Mick, D.G., and Fournier, S. (1998). Paradoxes of Technology: Consumer Cognizance, Emotions, and Coping Strategies, Journal of Consumer Research, 25(2), 123-143. doi: 10.1086/209531.

29. Mohr, J., Sengupta, S., and Slater, S. (2010). Marketing of high-technology products and innovations. New Jersey: Pearson Education Inc.

30. Moore, G.E. (1965). Cramming More Components Onto Integrated Circuits, Electronics, April 19, 1965. Electronics, 38(8), 82-85.

31. Moriarty, R.T., Kosnik, T.J. (1989). High-tech marketing: concepts, continuity, and change. MIT Sloan Management Review, 30(4).

32. Narver, J.C., Slater, S.F., and MacLachlan, D.L. (2004). Responsive and proactive market orientation and new-product success. Journal of Product Innovation Management, 21(5), 334-347. https://doi.org/10.1111/j.0737-6782.2004.00086.x.

33. Organization for Economic Cooperation and Development and Statistical Office of the European Communities (2005). The measurement of scientific and technological activities: guidelines for collecting and interpreting innovation. Oslo Manual. Paris: OECD Publishing.

34. Philips, D., Hallman, W. (2013). Consumer Risk Perceptions and Marketing Strategy: The Case of Genetically Modified Food. Psychology \& Marketing, 30(9), DOI: 10.1002/ mar.20642.

35. Sarin, S., Sego, T., and Chanvarasuth, N. (2003). Strategic use of bundling for reducing consumers' perceived risk associated with the purchase of new high-tech products. Journal of Marketing Theory and Practice, 11(3).

36. Sundbo, J. (1998). The Theory of Innovation. Entrepreneurs, Technology and Strategy. Northhampton: Edward Elgar.

37. Taranko, T., de Pourbaix, P. (2009). Niepewność w zachowaniach konsumentów i sposoby jej ograniczenia. In: L. Garbarski, J. Tkaczyk (eds.), Kontrowersje wokót marketingu w Polsce. Niepewność i zaufanie a zachowania nabywców (pp. 175-186). Warszawa: Wydawnictwo Akademickie i Profesjonalne. 
38. Tkaczyk, J., Awdziej, M. (2009). Istota i kategorie niepewności w odniesieniu do nabywców. In: L. Garbarski, J. Tkaczyk (eds.), Kontrowersje wokół marketingu w Polsce. Niepewność i zaufanie a zachowania nabywców (pp. 52-60). Warszawa: Wydawnictwo Akademickie i Profesjonalne.

39. Viardot, E. (2004). Successful Marketing Strategy for High-Tech Firms. Boston: Artech House.

40. Von Hippel, E. (1984). Novel Product Concepts from Lead User: Segmenting Users by Experience. Marketing Science Institute Working Paper, Report No. 84-109.

41. Wiechoczek, J. (2015). Źródła innowacji produktowych w sektorze wytwórców dóbra zaawansowanych technicznie, Logistyka, 2.

42. Wiechoczek, J. (2016). Tendencje w rozwoju marketingu mobilnego producentów dóbr zaawansowanych technologicznie. Studia Ekonomiczne. Zeszyty Naukowe Uniwersytetu Ekonomicznego w Katowicach, 254.

43. Wiśniewski, P. (2016). Marketing - relacja wymiany wartości. In: K. Klincewicz (ed.), Zarzadzanie, organizacje $i$ organizowanie - przeglad perspektyw teoretycznych. Warszawa: Wydawnictwo Naukowe Wydziału Zarządzania Uniwersytetu Warszawskiego. 44. Ziamou, P., and Ratneshwar, S. (2002). Promoting Consumer Adoption of HighTechnology Products: Is More Information Always Better? Journal of Consumer Psychology, 12(4), 341-351. http://doi.org/10.1207/S15327663JCP1204_0. 